Володимир Хміль

Національний університет оборони України імені Івана Черняховського, м. Київ

ORCID ID 0000-0002-1968-4559

DOI: $10.33099 / 2617-1775 / 2020-02 / 305-315$

\title{
ПІДГОТОВКА МИРОТВОРЦІВ ЗА СТАНДАРТАМИ ОРГАНІЗАЦІї ОБ'ЄДНАНИХ НАЦІЙ
}

В статті проведено аналіз навчальної підготовки миротворчого персоналу Організації Об'єднаних Націй (OOH) до операщій з підтримання миру та розподіл обов'язків за етапами підготовки у системі ООН. Еволючия миротворчої діяльності ООН спричинена появою комплексних операцій з підтримання миру призвела до формування нових вимог до підготовки миротворчого персоналу ООН, заснованих на всебічному аналізі та вивченому досвіді проведених операцій з підтримання миру. Підготовка миротворчого персоналу на етапі перед розгортанням $\epsilon$ базисною підготовкою, стандартизований мінімум якої встановлює Департамент миротворчих операцій ООН, тем не менш відповідальність за ї̈ якість несуть країни-контрибутори.

Ключові слова: Організачія Об'єднаних Націй; операції з підтримання миру; миротворча діяльність; навчальна підготовка; миротворчий персонал.

Постановка проблеми: Зміни, які відбулися у процесі реформування $\mathrm{OOH}$ 3 початку 2000 року призвели до реорганізації системи навчальної підготовки миротворців до операцій з підтримання миру. Багатонаціональний характер середовища операцій з підтримки миру та їх комплексність вимагає чіткого розуміння стандартизованих підходів ООН 3 підготовки миротворчого персоналу, особливо на етапі підготовки перед розгортанням.

Аналіз останніх досліджень і публікацій. Дослідження грунтується на нормативних документах $\mathrm{OOH}$, що регулюють питання навчальної підготовки миротворців, стандартизованих навчальних матеріалах Департаменту миротворчих операцій ООН, аналітичних матеріалах з миротворчої діяльності.

Метою статті є аналіз формування та актуальна стратегія щодо підготовки миротворчого персоналу до операцій з підтримання миру ООН.

Методи дослідження: системний аналіз, порівняння, класифікація, узагальнення та систематизація.

Виклад основного матеріалу. Миротворча діяльність Організації Об'єднаних Націй $(\mathrm{OOH})$, розпочата у 1948 році вносить унікальний вклад у вирішення конфліктів навколо світу. Однак серед багатьох операцій $\mathrm{OOH} 3$ підтримання миру існують моменти коли персонал $\mathrm{OOH}$ піддавався критиці щодо порушень несумісних з мандатом за причини низької підготовки. На початкових етапах миротворчої діяльності ООН проблематика підготовки миротворчого персоналу не викликала особливих дискусій серед країн-членів $\mathrm{OOH}$, доки не змінилася природа конфліктів (у своїй більшості від міждержавних до внутрішньодержавних) та комплексність самих операцій 3 підтримання миру і безпеки [7]. Сучасні операції з підтримки миру (ОПМ) $\mathrm{OOH}$ отримують більш місткі мандати, які передбачають завдання державного 
управління та пошуку шляхів вирішення конфлікту. Окрім військового у складі ОПМ з'явилися потужні поліцейські та цивільні компоненти, функції, яких повинні інтегруватися в єдину систему досягнення цілей мандату.

У 1965 році Генеральна Асамблея ООН створила Спеціальний комітет 3 миротворчих операцій (С-34) для проведення всебічного щорічного огляду миротворчих операцій у всіх їх аспектах [15]. У 1989 році С-34 вперше прозвітував про стан підготовки миротворчого персоналу до ОПМ та закликав держави-члени створити національні програми підготовки військовослужбовців та цивільного персоналу до ОПМ та, у зв'язку 3 цим, запропонувати Генеральному секретарю формат навчальних матеріалів, які держави-члени будуть використовувати, як керівництва для навчальних програм на національному, або регіональному рівні [16]. Таким чином було закладено основу для розподілу зусиль між $\mathrm{OOH}$ i державами-членами щодо стандартизованої підготовки миротворців до ОПМ ООН.

Незважаючи на роботу C-34 по удосконаленню навчальної підготовки миротворців, цьому питанню приділялося відносно менше уваги до 2000 року порівняно з іншими факторами, які вважалися вирішальними для ефективного збереження миру. Така ситуація була спричинена відсутністю оцінювання діяльності миротворців та відповідного зв'язку між підготовкою до ОПМ та їх проведенням.

Починаючи з 2000 року алжирський дипломат Лахдар Брахімі очолив роботу експертів ООН з виявлення критичних аспектів миротворчої діяльності $\mathrm{OOH}$ та підвищення ефективності ОПМ. Важливість питань професійної підготовки миротворців ООН зазначається у доповіді Брахімі 2000 року нарівні 3 такими важливими елементами, як політична підтримка та швидке розгортання [3]. У звіті підготовка розглядається, як частина «управлінського» підходу, який має застосовуватися у заходах з підтримання миру, та для того, щоб діяти злагоджено військові контингенти повинні бути підготовлені та оснащені відповідно до загальних стандартів [3, 114]. Також ООН було запропоновано встановити «мінімальні стандарти підготовки», які мають бути включені до Меморандуму про розуміння, який потенційні країниконтрибутори збройних сил будуть підписувати із Секретаріатом ООН перед розгортанням відповідної місії [3, 116]. Встановлення відповідних стандартів було впроваджено у рамках приєднання країн-контрибуторів до «Системи резервних угод $\mathrm{OOH»,} \mathrm{що} \mathrm{містить} \mathrm{інформацію} \mathrm{про} \mathrm{усі} \mathrm{наявні} \mathrm{ресурси} \mathrm{країн-}$ контрибуторів, які надаються для потреб операцій ООН. Але цей формат утримання резерву виявився недосконалим, тому з 2015 року ООН разом с країнами-членами розробила новий механізм - «Система забезпечення готовності миротворчого персоналу» (СЗГМП). Суть СЗГМП полягає у зобов'язанні країни-контрибутора мати окремі підрозділи, готові до участі у миротворчій діяльності ООН, що сприятиме скороченню строків розгортання збройних сил у нових місіях. Зокрема СЗГМП ООН передбачає чотири рівня готовності:

Рівень 1. Країна, що надає війська, офіційно зобов'язується надати підрозділ i передає перелік основного обладнання й майна для 
самозабезпечення, а також свідчення про завершення базової підготовки й перевірки на предмет дотримання прав людини. Державам-членам рекомендується вказати строки доставки й тривалість розгортання для кожного компонента всіх обіцяних засобів і сил;

Рівень 2. У зв'язку з оперативними потребами ООН, взяті зобов'язання на рівні 1 можуть бути підвищені до рівня 2 після оцінки та відвідання країни консультативною групою з штаб-квартири ООН;

Рівень 3. Після задовільної оцінки підрозділи, які досягли відповідного ступеню готовності, переходять на рівень 3;

Рівень швидкого розгортання. Досягнувши рівня 3 країна, яка надає війська може взяти на себе зобов' язання по розгортанню протягом 60 днів після отримання відповідного запиту від штаб-квартири ООН [11].

Проблематика миротворчої діяльності ООН, висвітлена у доповіді Брахімі була врахована в Доктрині «Операції ООН з підтримання миру: принципи та орієнтири» 2008 року [2], в якій визначено основні принципи та завдання ОПМ а також фактори, які сприяють успішному їх виконанню. Доктрина на цей час, $\epsilon$ основою для розробки навчальних матеріалів 3 підготовки військового, поліцейського та цивільного персоналу до участі в ОПМ ООН. Логічним продовженням процесу реформи навчальної підготовки ООН стала «Оцінка стратегічних потреб з підготовки миротворчого персоналу» [4] та формування нової стратегї миротворчої підготовки ООН, зазначеної у доповіді Генерального секретаря ООН «Про хід здійснення професійної підготовки 3 питань підтримання миру» у січні 2009 року (А/63/680) [18]. Зокрема в стратегії вперше зазначаються основні результати оцінки потреб професійної підготовки 3 питань підтримання миру на трьох головних етапах: етапі до розгортання, етапі прибуття у місію та етапі постійної підготовки, роль і функції відповідних управлінь та служб як у штаб-квартирі ООН так і у відповідних місіях ООН на місцях.

Вдосконалення та реалізація стратегії підготовки ООН у рамках реформи миротворчої діяльності деталізовані у неофіційному документі ДМО/ДОП «Нова програма партнерства: визначення нових горизонтів миротворчої діяльності ООН» 2009 року [10]. Основною ідеєю цього документу є підхід, орієнтований на спроможності, та визначається як підхід, що відходить від кількісної стратегї, до такої, що базується на навичках, спроможності та готовності персоналу, а також матеріальних засобах для забезпечення необхідних результатів. Цей підхід грунтується на чітких оперативних завданнях та стандартах для персоналу ООН, які пов'язані 3 відповідною підготовкою, та обладнанням, необхідним для виконання цих завдань [10, 29]. Перший крок до розбудови спроможностей, згідно Програми це «робота 3 країнами-членами для визначення чітких оперативних стандартів для важливих завдань мандату, які будуть використовуватися при розробці навчальних матеріалів та в підготовці до розгортання». У документі також зазначається, що «національний персонал та національний контингент потребують підготовки перед розгортанням, щоб сформувати знання та навички необхідні для виконання місії. Незважаючи на постійні вдосконалення підготовки для 
керівників (командирів) та загальних навчальних модулів, недостатньо підготовлений персонал все ще розгортається на місцях» $[10,31]$. Щоб подолати цю серйозну проблему, Програма закликає до миротворчого партнерства для створення ефективної глобальної навчальної мережі, куди може бути залучений досвідчений персонал, двосторонні та багатосторонні програми та мережі регіональних навчальних центрів.

Необхідно зазначити, що у рамках реформи, ООН було створено Відділ 3 питань політики, оцінки та навчальної підготовки (ВППОНП) у структурі якого важливу роль займає Об’єднана служба навчальної підготовки (ОСНП) головний підрозділ, який відповідає за навчальну підготовку 3 питань підтримання миру та призначений виконувати свої функції у співпраці 3 Департаментом Миротворчих Операцій (ДМО) та Департаментом Польової Підтримки (ДПП), який на сьогодні змінив назву на Департамент Оперативної Підтримки (ДОП). Зокрема ОСНП відповідає за визначення актуальних стандартів навчальної підготовки 3 питань підтримання миру, задовольняє потреби навчальної підготовки, надає підтримку та консультаційні послуги ДМО та ДОП, країнам-членам та місіям ООН на місцях з питань підготовки.

ОСНП співпрацює з партнерами в системі ООН і поза нею, особливо 3 основними офісами в рамках ДМО та ДОП, які мають координаторів 3 професійної підготовки, які відповідають за координацію та управління навчанням у своїй галузі спеціальності. Аналогічно, у кожній польовій місії $\mathrm{OOH} \epsilon$ навчальний координаційний центр, або інтегрований навчальний центр місії, відповідальний за надання специфічної для місії навчально-ознайомчої та безперервної підготовки для всіх миротворців. Співробітники ОСНП на базі логістичної бази $\mathrm{OOH}$ в місті Бриндізі, Італія, проводять обов'язкову попередню підготовку цивільних працівників безпосередньо перед їх направленням в місії.

У жовтні 2009 року ДМО та ДОП визначили п'ять напрямів, в яких ОСНП могла б підтримувати держави-члени та навчальні центри 3 підготовки миротворчого персоналу до ОПМ [12]:

1. Встановлення стандартів підготовки до розгортання, навчальних матеріалів та посібників;

2. Надання допомоги в розробці планів та навчальних програм підготовки до розгортання;

3. Підтримка підготовки інструкторів;

4. Сприяння обміну інформацією та двосторонньому партнерству між навчальними закладами;

5. Забезпечення «визнання» діючих військових та поліцейських курсів підготовки до участі у МОПМ.

Кожна з цих функцій, відіграє важливу роль у наданні допомоги державамчленам у забезпеченні належної підготовки до розгортання для військового і поліцейського персоналу, а також у впровадженні стандартизованих умов підготовки.

Також у системі підготовки ООН існує Навчальний та науководослідницький інститут ОOH (UNITAR) заснований в 1963 році. Серед 
основних завдань інститут визначає підготовку кадрів серед державних службовців країн-членів, які займаються питаннями підтримання миру та попередження конфліктів. На цей час інститут розробив перелік програм у тому числі дистанційних, які дозволяють навчатися зацікавленому персоналу за темами, актуальними в організації та проведення ОПМ.

Разом із країнами-членами ДМО і ДПП розробили «Політику підтримки підготовки військовослужбовців та поліцейських до операцій 3 підтримання миру ООН на етапі перед розгортанням» (жовтень 2009 року) та «Політику в області навчальної підготовки для усього миротворчого персоналу ООН» (травень 2010 року) [13], де зазначаються ролі ВППОНП та ОСНП, об'єднаних центрів підготовки миротворчого персоналу у Центральних органах ООН, місіях та держав-членів, та їх взаємодія щодо задоволення потреб підготовки. Також, вперше за всі роки реформи ООН, документ дає визначення миротворчої підготовки - «будь яка індивідуальна чи колективна підготовка 3 отримання військовослужбовцями, поліцейськими та цивільним персоналом ООН знань, навиків та ставлення, необхідних для виконання мандату, що дозволить ім:

а) бути готовими до непостійних викликів ОПМ, відповідно принципів, політики та настанов ДМО/ДПП а також вивченому досвіду;

б) виконувати свої професійні функції ефективно, на професійному рівні та з урахуванням комплексних завдань;

в) продемонструвати ключові цінності та повноваження ООН».

Напрями розбудови професійної підготовки ООН зазначені у доповіді Генерального секретаря ООН у січні 2009 року також відображені в контексті документів «Нові горизонти» 2010 року [5] та «Нові горизонти» 2011 року [6], які відображають суть розпочатої реформи миротворчої діяльності заснованої на реаліях та потребах комплексних (наявність у структурі військового, поліцейського, цивільного компонентів) операцій з підтримання миру. Зокрема в останньому - питання підготовки та освіти зазначаються у контексті розвитку потенціалу миротворчої діяльності.

Деталізація процесу реформи професійної підготовки була представлена у доповіді Генерального секретаря ООН «Про хід здійснення професійної підготовки $з$ питань підтримання миру» 2010 року (А/65/644) [19]. Зокрема в документі зазначається, що миротворча підготовка $\epsilon$ «сумісний обов'язок держав-членів, ДМО і ДПО ООН. Держави-члени забезпечують підготовку до розгортання операцій, а департаменти та польові місії відповідають за вступні навчальні курси та поточну підготовку».

Необхідно відмітити, що «Політика в області навчальної підготовки для усього миротворчого персоналу ООН» 2010 року зобов'язала ОСНП проводити періодичний аналіз потреб навчальної підготовки ООН, останній реліз якої вийшов у 2012 році під назвою «Глобальна оцінка потреб 3 підготовки миротворчого персоналу» [1]. Аналіз визначає пріоритетні потреби підготовки військовослужбовців через знання, які необхідно покращити, та навички, які необхідно вдосконалити (таблиця 1). 
Пріоритетні потреби підготовки військовослужбовців

\begin{tabular}{|c|c|}
\hline Знання, які необхідно покращити & Навички, які необхідно вдосконалити \\
\hline Роль ООН та її органів. & Комунікативні навички. \\
\hline $\begin{array}{l}\text { Миротворчість та політичні питання, для } \\
\text { розуміння як військові підтримують } \\
\text { політичний мандат. }\end{array}$ & $\begin{array}{l}\text { Уміння побудови звіту та презентації для } \\
\text { проведення якісних брифінгів. }\end{array}$ \\
\hline $\begin{array}{l}\text { Захист цивільних, захист дітей та інші } \\
\text { аспекти захисту прав людини. }\end{array}$ & Управління конфліктом. \\
\hline $\begin{array}{l}\text { Культурна обізнаність щодо країни, де } \\
\text { проводиться ОПМ та взаємодія з місцевим } \\
\text { населенням. }\end{array}$ & Координація з поліцією ООН. \\
\hline $\begin{array}{l}\text { Роль поліцейського та та цивільного } \\
\text { компонентів в ОПМ та } \\
\text { взаємодіють з військовими }\end{array}$ & $\begin{array}{l}\text { Застосування англійської і французької } \\
\text { мов, де це необхідно. }\end{array}$ \\
\hline Правила застосування сили. & Стрільба зі зброї. \\
\hline $\begin{array}{l}\text { Правила поведінки персоналу ООН та } \\
\text { наслідки у разі їх порушення. }\end{array}$ & $\begin{array}{l}\text { Водіння у складних умовах (у тому числі } \\
\text { на піску). }\end{array}$ \\
\hline
\end{tabular}

Реформа у галузі миротворчої підготовки сприяла формуванню подальшої стратегії $\mathrm{OOH}$ яка на цей час визначає три основні етапи підготовки до ОПМ [8].

1. Підготовка перед розгортанням: персонал отримує засновану на стандартах ООН загальну, спеціалізовану та у відповідних випадках адаптовану до умов конкретної місії підготовку з питань підтримання миру.

Для особового складу військових та поліцейських підрозділів ця підготовка проводиться інструкторами держав-членів, а для цивільного персоналу до рівня директора (Д1) - ОСНП. Відповідальність за підготовку миротворчого персоналу таким чином несуть держави-члени відповідно до Резолюції Генеральної Асамблеї ООН A/RES/49/37, 1995 року [17].

Слід зазначити, що у форматі підготовки перед розгортанням найбільшої уваги ДМО було приділено військовим спостерігачам (BC) $\mathrm{OOH}$, чиї завдання та потреби в підготовці визначені краще, ніж для інших категорій миротворців. Така увага $\epsilon$ небезпідставною ураховуючи, що ВС ОOН виконують завдання без зброї, у складному операційному середовищі, де встановлення миру ще відбувається та має перемінний характер. Спеціалізовані навчальні матеріали (СНM) ВС ООН 2019 року [20] $є$ останньою розробкою ОСНП ДМО, яка відміняє тренувальні матеріали з підготовки військових експертів (2010 року), де було передбачено підготовку офіцерів зв'язку, військових спостерігачів та військових радників. У нових СНМ ВС ООН 2019 року враховано такі аспекти, як захист цивільного населення, питання гендеру, управління ризиками 3 питань безпеки, саморобні вибухові пристрої. Перелік СНМ для ВС та інших напрямів підготовки представлений на електронному ресурсі ООН з питань миротворчої діяльності [9]. До них відносять а підготовки штабних офіцерів $\mathrm{OOH}$, підготовки сухопутного батальйону за специфікою місії, захисту дітей, цивільно-військової координації, офіцерів поліції ООН, сформованих 
поліцейських підрозділів, запобігання сексуальному насильству персоналом $\mathrm{OOH}$, сексуального насильства пов'язаного 3 конфліктом, підготовки військових підрозділів ООН (за специфікою місій ООН).

2. Підготовка в місіях: складається 3 вступного інструктажу та безперервної навчальної підготовки. Вступний інструктаж призначений для забезпечення знаннями миротворчий персонал 3 питань, які э важливими для місії, а також знаннями, які будуть сприяти їх найшвидшій інтеграції у систему та допоможуть їм якнайшвидше розпочати надавати підтримку діяльності місії. Безперервна навчальна підготовка проводиться протягом призначення у місії, та може включати відповідні заняття, направлені на перепідготовку та підвищення кваліфікації миротворчого персоналу. Безперервна навчальна підготовка включає ряд обов'язкових тематик, представлених у вигляді онлайн курсів, опановані усім миротворчим персоналом.

3. Функціональна підготовка полягає у навчанні навичкам необхідним для ефективної роботи миротворчого персоналу у відповідній сфері діяльності (військові експерти, поліцейські, співробітники з політичних питань та інші). Відповідно до цього ДМО було розроблено комплект навчальних матеріалів. Функціональна підготовка: включає підготовку керівного складу у системі ООН, спеціалізовану підготовку (для кожної складової ОПМ) та підвищення рівня підготовки за відокремленими тематиками (захист цивільного населення, захист дітей, запобігання сексуальному насильству, т.і.).

Хоча кожен етап підготовки $є$ важливим, підготовка до розгортання $\epsilon$ основоположною. Участь миротворчого персоналу в ОПМ ООН є доцільною лише після відповідної підготовки до розгортання, що дає можливість виконувати свої завдання з першого дня по прибуттю у місію. Підготовка в місіях і функціональна підготовка мають обмежений характер, враховуючи інші пріоритетні завдання, під час виконання відповідних обов'язків у місії. Підготовка після розгортання може заповнювати лише незначні прогалини у попередній підготовці, пов'язані з місією, чи виконанням специфічних функцій.

Окрім етапів, стратегія підготовки розрізняє три основні складові ОПМ: військова, поліцейська та цивільна. Кожна вимагає різного підходу до підготовки, не тільки у сенсі врахування різноманітності їх відповідних функцій, але й з огляду на різні способи відбору та розгортання. Зазвичай цивільний персонал відбирається через систему вакансій та процедур відбору $\mathrm{OOH}$ [14]. Це дозволяє ООН наймати персонал, який має навички та досвід, необхідний для виконання завдань, на відповідних посадах у штабах чи польових умовах. Суттєва відмінність у відборі цивільних осіб, на відміну від миротворців у формі, полягає в тому, що перші проходять відбір особисто а другі через свої національні органи виконавчої влади (Міністерство оборони/внутрішніх справ/поліції, тощо). Більшість військових проходять відбір колективно, як сформовані підрозділи (піхотний батальйон, інженерна рота т.і.). Поліцейська складова забезпечується обома методами, оскільки основна частина поліцейської складової набирається та розгортається у великих підрозділах, які називаються сформованими поліцейськими підрозділами, а решта - меншими, або окремо. 
Висновки: аналіз нормативних документів ООН та інших матеріалів стосовно підготовки миротворчого персоналу ООН проведений у статті засвідчує, що зазначена підготовка пройшла відповідний еволюційний період, який характеризується появою комплексних операцій з підтримання миру, а відповідно й наявністю завдань у таких операціях, які вимагають чіткої та гармонічної взаємодії військової, поліцейської та цивільної складової.

Організація оцінювання та аналізу ОПМ ООН сприяла формуванню нової стратегії ООН щодо підготовки миротворчого персоналу та створення оновлених навчальних матеріалів та відповідних навчальних програм у дистанційному форматі для військової, поліцейської та цивільної складових $\mathrm{O \Pi M} \mathrm{OOH.}$

Підготовка миротворців ООН на етапі до розгортання залишається базовою підготовкою, за якість якої відповідають держави-члени, тем не менш стандартизований підхід до навчальної підготовки в ООН зберігається завдяки розробці навчальних матеріалів з питаннями, актуальними на цей час в ОПМ $\mathrm{OOH}$.

\section{ЛIТЕРАТУРА}

1. Глобальна оцінка потреб з підготовки миротворчого персоналу - Заключний звіт, 2012-2013 pр. Департамент миротворчих операцій та Департамент польової підтримки ООН, 2012 p.

2. Доктрина «Операції ООН з підтримання миру: принципи та орієнтири». Департамент миротворчих операцій, Департамент польової підтримки ООН, 2008 р.

3. Доповідь Групи 3 питань операцій 3 підтримання миру («Доповідь Брахімі») $\mathrm{A} / 55 / 305, \mathrm{~S} / 2000 / 809$. [Електронний ресурс]. - режим доступу: https://www.un.org/en/events/pastevents/brahimi_report.shtml.

4. Доповідь Об'єднаної служби навчальної підготовки/Відділу з питань політики, оцінки та навчальної підготовки $\mathrm{OOH}$ щодо оцінки стратегічних потреб підготовки миротворчого персоналу, 2008. [Електронний ресурс]. - режим доступу: http://dag.un.org/bitstream/handle/11176/89580/2008\%20Strategic_Training_Needs_Assessment_Re port.pdf?sequence $=1 \&$ isAllowed $=\mathrm{y}$.

5. Ініціатива «Нові горизонти». Періодичний доклад № 1. Департамент миротворчих операцій та Департамент польової підтримки. Нью-Йорк, Жовтень 2010 р.

6. Ініціатива «Нові горизонти». Періодичний доклад № 2. Департамент миротворчих операцій та Департамент польової підтримки. Нью-Йорк, Грудень 2011 р.

7. Інститут економіки та миру. Глобальний індекс миру 2019. "Вимірювання показників відносно миру у складному світі”. Липень 2019. [Електронний ресурс]. - режим доступу: http://visionofhumanity.org/reports.

8. Інформаційний центр $\mathrm{OOH} з$ питань підтримання миру. Миротворча підготовка. [Електронний ресурс]. - режим доступу: https://research.un.org/en/peacekeepingcommunity/pre-deployment.

9. Інформаційний центр ООН з питань підтримання миру. Спеціалізовані навчальні матеріали. [Електронний ресурс]. - режим доступу: https://research.un.org/en/peacekeepingcommunity/training/STM.

10. «Нова програма партнерства: визначення нових горизонтів миротворчої діяльності ООН». ДМО/ДПП, липень 2009 р.

11. Операції ООН з підтримання миру. Військовий персонал. [Електронний ресурс]. режим доступу: https://peacekeeping.un.org/en/military.

12. «Політика підтримки підготовки військових та поліцейських до операцій 3 підтримання миру ООН на етапі перед розгортанням», ДМО/ДПП, Жовтень 2009 p. 
13. «Політика в області навчальної підготовки для усього миротворчого персоналу ООН». ДМО/ДПП, Травень 2010. [Електронний ресурс]. - режим доступу: http://dag.un.org/bitstream/handle/11176/401032/2010.20\%20DPKO_DFS_POL_TrainingforallUN PKPersonnel_1May2010.pdf? sequence=1\&isAllowed=y.

14. Портал ООН з питань людських ресурсів. [Електронний ресурс]. - режим доступу: https://inspira.un.org/psp/PUNA1J/?cmd=login\&languageCd=ENG.

15. Резолюція Генеральної Асамблеї ООН 2006 (XIX) (18 Лютого, 1965), UN Doc. A/RES/2006 (XIX).

16. Резолюція Генеральної Асамблеї ООН 44/49 (08 Грудня 1989 р.), UN Doc. A/RES/44/49.

17. Резолюція Генеральної Асамблеї ООН 49/37 (09 Лютого 1995 р.), UN Doc A/49/37.

18. Резолюція Генеральної Асамблеї ООН 63/680 (14 Січня 2009 р.), UN Doc. A/63/680.

19. Резолюція Генеральної Асамблеї ООН 65/644 (22 Грудня 2010 р.), UN Doc A/65/644.

20. Спеціалізовані навчальні матеріали з підготовки військових спостерігачів ООН до операцій з підтримання миру ООН, 2019. [Електронний ресурс]. - режим доступу: https://research.un.org/en/peacekeeping-community/training/STM/UNMO.

\section{REFERENCES}

1. Global Peacekeeping Training Needs Assessment - Final Report, 2012-2013. Integrated Training Service Department of Peacekeeping Operations and Department of Field Support United Nations, 2012.

2. United Nations Peacekeeping Operations Principles and Guidelines. UN DPKO, DFS, 2008.

3. Report of the Panel on United Nations Peace Operations ("Brahimi Report") A/55/305, S/2000/809. URL: https://www.un.org/en/events/pastevents/brahimi_report.shtml.

4. Report on the Strategic Peacekeeping Training Needs Assessment, 2008. URL: http://dag.un.org/bitstream/handle/11176/89580/2008\%20Strategic_Training_Needs_Assessment_Re port.pdf? sequence $=1 \&$ is Allowed $=\mathrm{y}$.

5. The New Horizon Initiative. Progress Report No 1. Department of Peace Operations and Department of Field Support. New York, October 2010.

6. The New Horizon Initiative. Progress Report No 2. Department of Peace Operations and Department of Field Support. New York, December 2011.

7. Institute for Economics \& Peace. Global Peace Index 2019: Measuring Peace in a Complex World, Sydney, June 2019. URL: http://visionofhumanity.org/reports (accessed July 20, 2020).

8. United Nations Peacekeeping Resource Hub. Peacekeeping Training. URL: https://research.un.org/ru/peacekeeping-community/pre-deployment.

9. United Nations Peacekeeping Resource Hub. URL: https://research.un.org/en/peacekeepingcommunity/training/STM.

10. DPKO/DFS, "A New Partnership Agenda: Charting a New Horizon for UN Peacekeeping," July 2009.

11. United Nations Peacekeeping. URL: https://peacekeeping.un.org/en/military.

12. DPKO/DFS, "Support to Military and Police Pre-Deployment Training for UN Peacekeeping Operations," UN Doc. Ref. 2009.21, October 2009.

13. Training for All UN Peacekeeping Personnel. UN DPKO/DFS, May 2010. URL: http://dag.un.org/bitstream/handle/11176/401032/2010.20\%20DPKO_DFS_POL_TrainingforallUN PKPersonnel_1May2010.pdf? sequence $=1 \&$ is Allowed=y.

14. UNHuman Resources Gateway. URL:https:/inspira.un.org/psp/PUNA1J/?cmd=login\&languageCd=ENG.

15. UN General Assembly Resolution 2006 (XIX) (February 18, 1965), UN Doc. A/RES/2006 (XIX).

16. UN General Assembly Resolution 44/49 (December 8, 1989), UN Doc. A/RES/44/49.

17. UN General Assembly Resolution 49/37 (9 February 1995), UN Doc A/49/37.

18. UN General Assembly Resolution 63/680 (January 14, 2009), UN Doc. A/63/680.

19. UN General Assembly Resolution 65/644 (December 22, 2010), UN Doc A/65/644. 
20. Specialised Training Materials United Nations Military Observers for United Nations Peace Operations, UN 2019. URL: https://research.un.org/en/peacekeeping-community/training/STM/UNMO.

\section{РЕЗЮМЕ}

Владимир Хмель,

Национальный университет обороны Украины имени Ивана Черняховского

\section{Подготовка миротворцев по стандартам Организации Объединенных Наций}

В статье проведен анализ учебной подготовки миротворческого персонала Организации Объединенных Наџий (ОOH) $\kappa$ операџиям по поддержанию мира $u$ распределения обязанностей по этапам подготовки в системе ООН. Эволючия миротворческой деятельности ООН вызванная появлением комплексных операций по поддержанию мира привела $\kappa$ формированию новых требований $\kappa$ подготовке миротворческого персонала, основаных на всестороннем анализе и изученном опыте проведенных операчий по поддержанию мира. Подготовка миротворческого персонала на этапе перед развертыванием является базисной подготовкой, стандартизованный минимум которой устанавливает Департамент миротворческих операџий ООН, тем не менее ответственность за ее качество несут страны-контрибюторы.

Ключевые слова: Организачия Объединенных Наций; операџии по поддержанию мира; миротворческая деятельность; учебная подготовка; миротворческий персонал.

\section{SUMMARY}

Volodymyr Khmil,

National Defence University of Ukraine named after Ivan Cherniakhovskyi

\section{Training of peacekeepers to United Nations Standards}

Introduction. Changes in the United Nations (UN) reform process since early 2000 have led to a reorganization of the peacekeeping training system for peacekeeping operations. The multinational nature of the UN peacekeeping operations environment and their complexity require a clear understanding of UN standardized approaches to training peacekeepers, especially in the pre-deployment phase.

Purpose. Analysis of evolution of UN training strategy and its current characteristics.

Methods: System analysis, comparison, classification, generalization and systematization.

Results. The article contains an analysis of training of the UN peacekeeping personnel for peacekeeping operations and distribution of responsibilities by training stages in the UN system. The evolution of UN peacekeeping activities caused by the emergence of complex peacekeeping operations has led to the formation of new requirements for the training of peacekeeping personnel, based on a comprehensive analysis and lessons learned of conducted peacekeeping operations. Pre-deployment training for peacekeeping personnel is a basic training, the standardized minimum of which is set by the UN Department of Peacekeeping Operations, but the responsibility for its quality rests with the contributing countries.

Originality. The scientific novelty of the study is the analysis of the UN approaches to the formation of training strategy for peacekeeping operations, which determines the thematic focus and distribution of tasks by stages of training in the UN system. Currently, this topic is paid less attention, than other issues relating to peacekeeping activities in Ukraine. The practical significance of this research refers to the informative material for assessing the strategy of training peacekeepers according to UN standards, identifying the main directions and focusing efforts on training peacekeepers for peacekeeping operations. 
Conclusion. Analysis of UN reports and other materials on the training of UN peacekeeping personnel conducted in the article shows, that this training has undergone an appropriate evolutionary period, which is characterized by emergence of complex peacekeeping operations. Thus the tasks for mentioned operations got wider spectrum with formation of new training strategy, which covers military, civilian and police components.

Development of UN training strategy based on comprehensive analysis and lessons learned from conducted UN peacekeeping operations has tendency for further changes consider complexity of operational environment in UN peacekeeping operations.

The pre-deployment training of peacekeeping personnel remains the main training where member states responsible for its quality, however, a standardized approach to training rests for UN, maintained through the development of standard training materials and requirements for peacekeeping personnel.

Key words: United Nations; peacekeeping operations; peacekeeping activity; training; peacekeeping personnel. 